\title{
The molecules and mechanisms of heart development, disease and regeneration
}

\author{
Eric N. Olson ${ }^{1,2}$ \\ From 2nd International Genomic Medical Conference (IGMC 2013) \\ Jeddah, Kingdom of Saudi Arabia. 24-27 November 2013
}

We seek to define the gene regulatory networks that govern heart development and disease. Recently, we discovered that the hearts of neonatal mice can fully regenerate after partial surgical resection or myocardial infarction, but this capacity is lost early in life. We are currently exploring the molecular underpinnings of the neonatal regenerative response of the heart, with the long-term goal of discovering combinations of genes and drugs that promote cardiac repair and regeneration. Promotion of cardiomyocyte proliferation through activation of the Yap pathway and modulation of epicardial signaling systems have shown efficacy in enhancing these processes. We are also optimizing strategies for reprogramming of cardiac fibroblasts toward a cardiac cell fate as a means of replacing cardiomyocytes in injured hearts. We have shown that four transcription factors can cooperatively reprogram fibroblasts into cardiac-like myocytes in vitro, albeit relatively inefficiently. Forced expression of these factors in dividing non-cardiomyocytes in mice also allows reprogramming into functional cardiac-like myocytes, improves cardiac function and reduces adverse ventricular remodeling following myocardial infarction. Screens for small molecules and microRNAs that enhance cardiac reprogramming have revealed new insights into the mechanistic basis of this process and have allowed further optimization in human cells. Opportunities and obstacles in the path toward mammalian cardiac regeneration will be discussed.

\section{Authors' details}

${ }^{1}$ University of Texas Southwestern Medical Center, Dallas, TX, USA. ${ }^{2}$ Center of Excellence in Genomic Medicine Research (CEGMR), King Abdulaziz

University, P.O. Box: 80216 Jeddah 21589, Kingdom of Saudi Arabia.

Published: 2 April 2014

Correspondence: eric.olson@utsouthwestern.edu

${ }^{1}$ University of Texas Southwestern Medical Center, Dallas, TX, USA

Full list of author information is available at the end of the article
doi:10.1186/1471-2164-15-S2-021

Cite this article as: Olson: The molecules and mechanisms of heart development, disease and regeneration. BMC Genomics 2014 15(Suppl 2): O21.
Submit your next manuscript to BioMed Central and take full advantage of:

- Convenient online submission

- Thorough peer review

- No space constraints or color figure charges

- Immediate publication on acceptance

- Inclusion in PubMed, CAS, Scopus and Google Scholar

- Research which is freely available for redistribution

\section{() Biomed Central}

C Biomed Central

(c) 2014 Olson; licensee BioMed Central Ltd. This is an Open Access article distributed under the terms of the Creative Commons Attribution License (http://creativecommons.org/licenses/by/2.0), which permits unrestricted use, distribution, and reproduction in any medium, provided the original work is properly cited. 